\title{
Breaking with Convention: Turkey's New Approach to Peacebuilding
}

\section{Onur Sazak and Auveen Elizabeth Woods}

\section{INTRODUCTION}

Turkey owes its status as a rising power to the steady political and economic development that it enjoyed in the initial years of the twenty-first century and to the weakening of the Western, rule-based liberal order. This has enabled regional actors with relative economic stability and security to assume certain responsibilities that traditionally fell to the Great Powers in the Cold War era. Like most BRICS countries and other rising powers, Turkey has ridden the tailwinds of this global opening. Turkey also shares with some other rising powers the experience of rapid economic growth, relative stability, and an ongoing political transition and reform. As the world shifts to a more multipolar system, Turkey has been using its religious, ethnic, and cultural ties to try to consolidate its soft power, both regionally and further afield. During this period, Turkey has

O. Sazak (州)

Support to Life, Sabancı University, Istanbul, Turkey

A.E. Woods

Istanbul Policy Center, Sabancı University, Istanbul, Turkey

(C) The Author(s) 2017

C.T. Call, C. de Coning (eds.), Rising Powers and

Peacebuilding, Rethinking Peace and Conflict Studies,

DOI 10.1007/978-3-319-60621-7_5 
raised its profile as a regional actor and an emerging power, especially as the Arab Spring produced opportunities, crisis, and warfare on its borders.

These lessons, as well as the country's status as a European Union candidate, a committed NATO ally, and a buffer state for the West, heighten Turkey's role in the facilitation of peace in the region and reinforce its image as a bridge between geographical and cultural divides.

As a Western-oriented, secular state with a majority Muslim population, Turkey is increasingly regarded as a pivot in effectively addressing both humanitarian and security aspects of the entrenched conflicts in Syria and the greater Levant. Turkey hosts approximately 2.8 million Syrian refugees (UNHCR, February 2017). At the same time it provides support for opposition forces in Syria and allowed members of the anti-IS (Islamic State) coalition, such as the USA to use its airbases. For much of its history, however, Turkey has been plagued by rampant insecurity and economic and political instability. It has experienced four military coups and a 30-year armed insurgency. As such, Turkey's recent activities may be supported by economic and international shifts in power, but its conceptualization and approach to peacebuilding is very much informed by the country's experiences of insecurity. ${ }^{1}$

\section{The Emergence of Turkish Peacebuilding}

Security and stability are two central issues that have guided Turkey's strategic considerations. In the wake of World War I and the fall of the Ottoman Empire, modernization through alignment and membership of Western institutions was seen as crucial to preserving the security and stability that had been lost in the preceding years. It is also in this context that some of the traditional principles of Turkey's foreign policy have emerged, such as non-interference and respect for sovereignty. Turkey's domestic and foreign policies have also been significantly influenced by the founder of the Republic, Mustafa Kemal Atatürk. A number of his speeches, particularly the phrase "Peace at home, peace in the world" have been used to frame Turkey's international engagement, from its first forays into peacekeeping in the 1990s to recent peacebuilding activities. Former Prime Minister Ahmet Davutoğlu had also reiterated this principle stating that Turkey has tried to build a proactive foreign policy based on peace and stability at home (2012). This ideal, however, has come under significant strain since the Arab Spring spread to the Levant, and its transformation into a violent civil war in Syria and rampant insecurity in Iraq. These issues have directly 
affected Turkey's own security and stability. The suicide attacks since the June 7,2015 general elections that have hit major towns in the southeast, the Turkish capital Ankara, and the country's largest city Istanbul, are nearly all traced to IS cells that infiltrated the porous borders in the South. This has been accompanied by renewed clashes between Turkish security forces and the PKK (The Kurdistan Workers' Party), which are equally detrimental to Turkey's stability and its image as a "peacemaker." In an additional blow to Turkey's security, it endured a coup attempt on July 15 , 2016, which led to the purging of thousands from the military, education institutions, and judicial and state agencies.

For much of Turkey's history, security, and stability were conceived in military terms and in relation to territorial integrity. Turkey's first and only international intervention during the Cold War was its mediation between Iran and Iraq in the 1980s. This can be seen from a traditional security perspective, given the proximity of both countries to Turkey's eastern flank. Following the loosening of the Cold War strictures, the Turkish International Cooperation and Development Agency (TIKA) was established in 1992 with the objective of expanding Turkish relations with the newly independent Turkic States of Central Asia. TIKA was conceived as a mechanism of Turkish soft power through cooperation in the economic, cultural, and humanitarian fields (Murphy and Sazak 2012). For much of this period, however, TIKA was left to languish as an agency due to internal instability and a focus on a harder, security-driven concept of military engagement. Turkey's first foray into peacebuilding during this time was in the Balkans in the 1990s, contributing troops to multilateral peacebuilding and peace enforcement missions with the United Nations (UN) and North Atlantic Treaty Organization (NATO).

The shift from such hard security-based peacebuilding to the civilian participation and technical assistance that characterizes Turkey's activities in recent years was facilitated by a change in domestic dynamics. Over the last decade, the Turkish Armed Forces has been losing its influence in foreign policy matters, which are now primarily determined by civilians in government. This was accompanied by expanded civilian and police participation in peace operations, increased engagement in multilateral organizations, and a revival of TIKA activities. Facilitated by a period of relative political and economic stability and internal reforms that eased restrictions in political, religious, and social spheres, Turkey began to expand its official development. Although retaining a strong military was a necessity due to the instability of the surrounding region, under the 
Justice and Development Party (AKP) civic and economic power was promoted as a more sustainable method of foreign engagement (Murphy and Woods 2014).

Domestic changes were accompanied by a restructuring of Turkish foreign policies priorities and goals under the AKP. This has served to both promote the prestige of a more internationally active Turkey and to reinforce the success of the country's leadership to a domestic audience (Achilles et al. 2015). Guided by then-Prime Minister Ahmet Davutoğlu (key adviser and later foreign minister from 2009-2014), a multilateral foreign policy emerged that sought a balance between proactive engagement and crisis management. Turkish leaders have emphasized the need for preventive diplomacy that should be intricately linked to any conflict management strategies, whether it is peacekeeping or peacebuilding activities. Identifying mediation and dialogue as essential tools in this preventative diplomacy, officials have stated that "peace mediation and facilitation efforts are the most cost-effective and efficient way of preventing and resolving conflicts" (United Nations Security Council 2011). Reflecting this position, Turkey has headed a number of initiatives. In 2005 the Alliance of Civilizations, which promotes interreligious and intercultural dialogue, was launched by the Prime Ministers of Spain and Turkey. In 2010, Turkey and Finland created a "Group of Friends of Mediation" consisting of 41 countries that support efforts by the UN and regional organizations in the area of mediation. And in May 2016, Turkey hosted the first World Humanitarian Summit, in Istanbul. These are diverse and cross-cultural examples that Turkish officials have identified as reflecting the country's approach to peacebuilding (Davutoğlu 2014). Through these initiatives Turkey has sought to promote flexibility, trust, and cooperation as the basis of successful mediation. In parallel to these efforts, Turkey launched a process on peacebuilding during its time on the Security Council from 2009-2010, which included these initiatives and brought together the Council for thematic meetings in Istanbul from 2010 to 2013 (Turkish Ministry of Foreign Affairs 2016).

Issues around "hard security" are still a strategic priority for Turkey's foreign policy, as seen in the country's engagement in Syria. But conceptualizations of security have broadened. As Davutoğlu stated, "stability cannot be built on the basis of force alone," (Davutoğlu 2012). Referencing the decade of reforms inside Turkey, Turkish officials have sought to find a balance between freedom and security in order to achieve stability (Murphy and Sazak 2012). Over the years, the concept of "security" 
has become more multidimensional, focusing on human needs through good governance and economic stability. This is evident in Turkey's rhetorical embrace of "humanitarian diplomacy," an ambiguous concept that Turkish officials have increasingly used to frame its repositioning in the aftermath of the Arab Spring. Humanitarian diplomacy as a concept claims to reject state-centric realpolitik and external interference in domestic affairs. Highlighting the importance of acknowledging "local values" and local ownership, it instead emphasizes the need to put human dignity and human security at the forefront of policy considerations (Keyman and Sazak 2014). There are of course limits to such aspirations, which can be seen Turkey's strategic engagement to the crises in Iraq and Syria.

\section{The Tools of Turkish Peacebuilding}

There is no concept paper that explicitly describes Turkey's definition of peacebuilding. It can, however, be understood through bilateral and regional activities, norms, and discussions, such as those already mentioned, that have emerged among the country's representatives over the last decade. Most Turkish officials discuss the term peacebuilding within the context of development and reconstruction of a conflict-affected country. Turkey's approach to peacebuilding can be characterized as a twofold process, encompassing both statebuilding and peacemaking within society. Reflecting a structural approach to peacebuilding, Turkish officials emphasize the centrality of good governance, strong responsive institutions, and rule of law for building an effective state and, therefore, in their view, a stable and peaceful society. ${ }^{2}$ Activities related to these goals by officials include infrastructure projects, technical assistance, and capacitybuilding programs for state institutions and personnel. This kind of structural peacebuilding must also be accompanied by an inclusive peacemaking process at all levels. Turkish officials feel that this is only possible through national ownership of goals and culturally sensitive engagement with all stakeholders, including civil society, professional associations, and women. This is particularly important with regard to political institutions and inclusive economic recovery, which Turkish officials say are essential for a peaceful society. Activities associated with societal peacebuilding include mediation efforts, education programs, religious support, and inclusive economic development.

Like other rising powers, economic interests are intricately linked to Turkey's foreign policy and its peacebuilding activities. Such interests 
have not only led to financial dividends for Turkey in the past but also promoted peace in some cases. Notably, the historically tumultuous relationship between Turkey and its Kurdish neighbors in Iraq has greatly improved with ongoing military cooperation between the administrations in Ankara and Erbil. The expansion of economic and diplomatic relations with Iraqi Kurdistan not only helped to improve relations, but was also a lucrative partnership (Hacaoğlu 2014). At the time, exports to Iraq in 2013 reached $\$ 12$ billion, with $\$ 8$ billion going to the Kurdish Regional Government, becoming one of Turkey's largest export markets (Çăgaptay et al. 2015). There are also some links between Turkey's economic interests and its aid practices in general. In Afghanistan, Turkish companies ranked fifth in terms of total number of foreign investors, with 140 registered in the country in 2013 (Çolakoğlu and Yegin 2014). Turkey's bilateral trade with Somalia was $\$ 72$ million by 2015 . Officials have also been frank about their interest in expanding economic relations with Somalia, one of the most prominent countries in Turkey's development activities. ${ }^{3}$ While not a specific policy, a pattern has emerged in which the establishment of a diplomatic presence in a new country is often soon followed by investment from Turkish companies and new flight links through Turkish Airlines.

Turkish diplomats are firm in their conviction that trade is better than aid for development. ${ }^{4}$ Many Turkish officials regard economic development, ideally through the diverse participation of the society as an essential component of peacebuilding, with one diplomat stating “[W]e don't think that peacebuilding could achieve its goals if there is no economic recovery and participation of the whole part of the society in the program." ${ }^{5}$ Officials believe economic investment provides alternative financial opportunities to criminality and extremist narratives, and supports national ownership of development.

Many of the initiatives that Turkish officials consider as peacebuilding activities are funneled through Turkish development aid. In 2014, Turkey's Official Development Assistance (ODA) was \$3.6 billion (TIKA 2016). This represents nearly a 30 percent increase between 2012 and 2014 alone (see Fig. 5.1). ${ }^{6}$ Despite Turkey's participation in a number of multilateral initiatives, the vast majority of this aid is provided in bilateral assistance. For example, in 2013 , only $\$ 151$ million of $\$ 3.3$ billion of ODA was provided through multilateral contributions (TIKA 2016,8). In 2014, this was $\$ 88$ million (TIKA 2016, 9). This illustrates Turkey's preference for bilateral engagement. 




Fig. 5.1 Turkey's development assistance 2002-2014 (\$US millions)

Turkey has expanded its activities to some of the world's most entrenched conflicts. From 2011 until 2014, Syria, Somalia and Afghanistan were among the top five largest recipients of Turkish ODA (TIKA 2012; 2013; 2014a, b; 2016). While Turkey does provide support to non-Muslim countries such as Ukraine, Macedonia, and Kenya, to name just a few, the bulk of the State's activities appear to be carried out in Muslim majority states. Many of these countries would also be on the list of least developed or fragile states. Examples of both the structural and social peacebuilding approaches of Turkey are evident in its activities in conflict-affected countries like Afghanistan, Somalia, and Balkan countries such as Bosnia and Herzegovina and Kosovo.

Much of what can be defined as Turkey's structural peacebuilding activities consist of technical capacity programs, infrastructure projects, and the provision of basic services that are focused on the recipient state institutions. Technical assistance, or cooperation as it is alternatively called, is broadly defined by Turkey as "strengthening capacities and effectiveness of individuals, organizations and institutions through transfer of ideas, technologies, knowledge and skills" (TIKA 2014b, 25). This can include a wide range of activities from the state to the local level such as trainings and scholarships to the provisions of equipment and materials. Additionally, a strong understanding of constructive development is common to both Turkish state agencies and non-state actors has strong historical roots. 
Since the Ottoman Empire, privately funded philanthropic development has focused on the construction of buildings and infrastructure, as well as the funding of services such as schools, hospitals, and mosques (Bikmen 2008). Examples of infrastructure projects include renovating state buildings such or building schools and roads are common across all the countries in which Turkey is engaged.

Many infrastructure and technical cooperation programs appear to focus on improving the provision of basic services such as medical and judicial standards. For example, Turkey provides a range of trainings from judges and prosecutors in Kosovo to medical staff in Somalia (TIKA $2014 a, b)$. Turkish officials have said that they feel capacity-building programs directly support statebuilding by legitimizing the state's authority and making services more effective. From this perspective, a legitimate and effective state is a form of peacebuilding that offers alternatives to non-governmental organizations such as militant or secession groups. However, Turkish officials are quick to emphasize that their support must be seen as apolitical in nature, stating: "We can only offer them certain technical expertise without any strict recipe. It is after all the requirements of the host country to determine how they will proceed."7

Technical assistance and capacity-building programs are also a characteristic of Turkey's social peacebuilding, given their broad definition and aims. Most of capacity-building programs include training and technical assistance to support economic empowerment and appear to be focused at the local level through municipalities and communities. Technical equipment assistance has been provided, for example, to the Governorship of Sar-e Pol in Afghanistan for vocational training programs for women, and the Agricultural Development Project in East Bosnia was established to support the return of families from the 1992-1995 war (TIKA 2014a, b). These are just some of the local projects aimed at economically empowering communities. Technical assistance is also a part of other social peacebuilding activities in the education field, such as providing technical equipment for high schools and universities.

Education initiatives have been one of the more widely known areas associated with Turkey's peacebuilding activities. This is due in part to the publicity around its extensive scholarship programs in Somalia. State scholarships have been provided by, among others, Diyanet (the Ministry of Religious Affairs) and the Education Ministry to students from Central Asia, Africa, the Middle East and Eastern Europe (Türkiye Bursları). Most education programs in the past had been run by third sector organizations 
such as Hizmet or Gülen-linked schools. In many countries programs associated with this group have since been closed. The Turkish state tends to run smaller education-orientated programs, such as providing school materials and equipment, funding and renovating buildings, and promoting Turkish language and cultural courses. Education initiatives such as these are not only a method of expanding Turkish soft power, but are also felt to contribute to social peacemaking through intercultural dialogue. Both officials and third state actors believe that education is a key peacebuilding tool that can counter the narrative of extremism and provide opportunities for the future.

Finally, Turkey's social peacebuilding activities are also characterized by an emphasis on mediation and religiously sensitive programs. Officials have stated the importance of mediation, not only at an inter-state level but also at the local level, through everyday activities and engagement with locals. This may range from consulting with communities to discussions with political authorities on bilateral projects. Turkish officials feel that mediation and consultation are mechanisms that support their own espoused principles of national ownership. These principles can perhaps also be seen to guide the concept of cultural and religiously sensitive programs. These range from sponsoring intercultural activities such as visits to Turkey or football tournaments to providing Qurans or circumcision ceremonies for boys for example, in countries such as Afghanistan and Niger (TIKA 2014a, b; 2016). The building of mosques or events during Islamic festivals such as book fairs or Iftar have been staged from Afghanistan to Mogadishu and Pakistan. Given the scope of these programs globally, religious sensitivity is clearly a central aspect of Turkey's activities. Such programs are not only pragmatic but they also add legitimacy to Turkish activities in the eyes of locals. In Afghanistan, reports noted that Turkish projects were more acceptable to communities than others because of their perceived sensitivity to local Afghan culture (Murphy and Sazak 2012).

\section{IMPACT AND CONCLUSIONS}

Over the last decade, Turkey's approach to peacebuilding has transformed from the strategic state-centric security engagement of the 1990s to a more multifaceted conceptualization that encompasses both statebuilding and social peacemaking. This has been facilitated by a change in civilmilitary power dynamics since 2000 and a broader understanding of security that considers the issue of human needs. Peacebuilding activities in 
recent years range from technical assistance for state services to education and religious programs. This has been developed in parallel with new foreign policy activities that emphasize both mediation and enhanced economic ties as potential peacebuilding strategies that are of mutual benefit to both Turkey and recipient states.

In spite of Turkey's good intentions to promote peace and stability in its region and the rest of the world, Ankara's capacity to execute this vision has some shortcomings. An estimated 2.8 million Syrian refugees, the resurgence of war with the PKK, IS' penetration deep into the country's urban centers, the continuing political volatility in the aftermath of the July 15 coup attempt and a receding economy constitute serious obstacles to the sustainability of Turkey's peacebuilding operations. In addition, for the last several years Turkey's ambitious foreign policy goals and determination to project its soft power have alienated various supporters. Counting on African support to win another term on the UN Security Council in 2016, Turkey only received the votes of 60 countries out of 193 (Sassounian 2014).

Turkey's struggle against the Gülen network over the last few years, which is accused of orchestrating the July 15 coup attempt in addition to undermining the government of the AKP, has also affected the country's relations with developing countries. Ironically, Gülenist charity organizations had been among the most visible non-governmental organization (NGOs) in providing humanitarian assistance to sub-Saharan Africa (Sassounian 2014). Viewed in light of Turkey's false predictions about the longevity of the Assad regime in Syria, Ankara's recognition of the depth of the crises that it is trying to help resolve both domestically and internationally, and its influence over the respective parties is challenging. In other words, the rhetoric-capacity mismatch in Turkish foreign policy risks moving Turkey farther away from "zero problems with neighbors" toward the dangerous territory of "zero neighbors without problems" (Sassounian 2014).

A number of basic organizational challenges have also hindered the Turkish state from realizing its potential to increase the quality and range of its peacebuilding initiatives. The most persistent of these impediments is coordination problems. First identified in a 2012 report a lack of effective interagency cooperation has been the most visible problem in Turkish peacebuilding activities (Sassounian 2014). The most vital ministries and government agencies that are involved in peacebuilding operations, such as the Foreign Ministry, Health Ministry, Development Ministry, and TIKA, were not informed about each other's activities both at the higher echelons 
of decision making or in the field. Recent research indicates that very little progress has been made in this area in recent years at both the state and third sector levels (Achilles et al. 2015). One representative of an international organization based in Ankara volunteered that most TIKA bureaucrats in charge of coordination are not even familiar with the basic UN procedures and terms. ${ }^{8}$ The lack of institutional training and knowledge of procedures within organizations like TIKA also complicates communication and coordination between the field offices and Ankara. In such situations, the quality and effectiveness of the country programs often depends on the individual in the field office. If the person assigned to a country office is in fact interested in the mission, TIKA operations in that particular country often provide more substantive results for the beneficiaries. ${ }^{9}$

This lack of consistency in coordination and consistent implementation of principles and goals also affects the development and monitoring of programs. There is a disparity between the prestige and rhetoric around Turkey's engagement and the actual effectiveness of the activities implemented. While TIKA publically provides data on the number of participants or equipment involved in technical assistance programs, greater analysis on how these programs are determined or their impact is not made available. There have been reports in the past of peacebuilding programs such as infrastructure projects or trainings being implemented without consultation with local authorities or research on other aid groups working in the area (Larson 2015; Deloffre 2015; Gloyd 2015). These problems appeared to have occurred in countries that TIKA had become newly active in, such as Somalia, Senegal, or Uganda. ${ }^{10}$ This also indicates an important vacuum in the pre-deployment analyses and monitoring activities for state operations in the field. Such patterns can, however, exacerbate overcrowding, duplication, and waste.

These internal capacity issues that the Turkey has grappled with have undoubtedly been exacerbated by the post-coup purges that have ravaged state institutions, agencies, and civil society organizations. In addition to these problems is the equally detrimental challenge of financing international operations. The influx of Syrian refugees, for instance, has cost the state an estimated $\$ 12$ billion (BirGün 2016) and led to nearly $\$ 2$ billion worth of resources being rechanneled from foreign operations. This has diverted significant Turkish resources from high profile activities in fragile countries such as Somalia (Achilles et al. 2015). In addition, the volatility of the Turkish lira against hard currencies, as well as ongoing political uncertainty, has taken a toll on the economic stability that is necessary to sustain the funds for Turkey's peacebuilding initiatives. 


\section{Notes}

1. Interview with a Turkish Diplomat, June 2015, and Foreign Ministry Official, March 2015.

2. Telephonic interview with a Turkish Foreign Ministry Official, March 2015, Ankara.

3. Interview with Turkish Foreign Ministry Officials, August 2015.

4. Interview with a Turkish Diplomat, February 2014.

5. Telephonic interview with a Turkish Foreign Ministry Official, June 2015, Ankara.

6. This graph is the authors' compilation based on official statistics from the Turkish Cooperation and Coordination Agency.

7. Interview with a Turkish Diplomat, 2015.

8. Interview with a UNDP-TIKA Coordinator, 2015.

9. Ibid.

10. Ibid.

\section{REFERENCES}

Achilles, Kathryn, Onur Sazak, Thomas Wheeler, and Auveen Elizabeth Woods. 2015. Turkish Aid Agencies in Somalia: Risks and Opportunities for Building Peace. March 2015 Report. Saferworld and Istanbul Policy Center. Available at https://www.files.ethz.ch/isn/189390/turkish-aid-agencies-in-somalia.pdf

Bikmen, Filiz. 2008. The Rich History of Philanthropy in Turkey: A Paradox of Tradition and Modernity. In Philanthropy in Europe: A Rich Past, a Promising Future, ed. N. MacDonald and L. Tayart de Borms, 223-234. London: Alliance Publishing Trust.

BirGün. 2016. umhurbaşkanı Erdoğan, Alman ARD televizyonuna konuştu. BirGün, July 26. Accessed August 1, 2016. http://www.birgun.net/haberdetay/cumhurbaskani-erdogan-alman-ard-televizyonuna-konustu-121521. html

Çağaptay, Soner, Christina Bache Fidan, and Ege Cansu Saçıkara. 2015. Turkey and the KRG Signs of Booming Economic Ties. The Washington Institute for Near East Policy. Accessed February 12, 2017. http://www.washingtoninstitute.org/ policy-analysis/view/turkey-and-the-krg-signs-of-booming-economic-tiesinfographic

Çolakoğlu, Selçuk, and Mehmet Yegin. 2014. The Future of Afghanistan and Turkey's Contributions. Istanbul: International Strategic Research Organization (USAK).

Davutoğlu, Ahmet. 2012. Principles of Turkish Foreign Policy and Regional Political Structuring. Center for Strategic Research 3. http://sam.gov.tr/wpcontent/uploads/2012/04/vision_paper_TFP2.pdf 
2014. Republic of Turkey Ministry of Foreign Affairs. Speech at the Ministerial Conference of the Non-Aligned Movement, Algeria, May 28. http://www.mfa.gov.tr/speech-delivered-by-h_e_-mr_-ahmet-davuto\%C4\%9 Flu-at-the-ministerial-conference-of-the-non_aligned-movement_-28-may2014_-algeria.en.mfa

Deloffre, Maryam. 2015. International NGO Behavior and Interactions with States. Presentation at the IPC-TİKA workshop on International Humanitarian NGOs and Health Aid, Istanbul, March 27.

Gloyd, Stephen. 2015. Sustainability of Health Aids. Presentation at the IPCTIKA Workshop on International Humanitarian NGOs and Health Aid, Istanbul, March 27. Group of Friends of Mediation. United Nations. Accessed February 1, 2016. http://peacemaker.un.org/friendsofmediation

Hacaoğlu, Selcan. 2014. Turkey Embracing Iraq's Kurds as Trade Erodes Old Enmity. Bloomberg Business, July 11. Accessed February 12, 2017. http:// www.bloomberg.com/news/articles/2014-07-10/turkey-s-embraceof-iraqi-kurds-shows-trade-eroding-old-enmity

Keyman, Fuat, and Onur Sazak. 2014. Turkey as a Humanitarian State. Project on the Middle East and Arab Spring Paper 2.

Larson, Paul. 2015. Logistics of Health Aids. Presentation at the IPC-TIKA workshop on International Humanitarian NGOs and Health Aid, Istanbul, March 27.

Murphy, Teri, and Onur Sazak. 2012. Turkey's Civilian Capacity in Post-Conflict Reconstruction. Istanbul: Istanbul Policy Center. https://research.sabanciuniv. edu/21550/1/IPM-Turkish-CivCap.pdf

Murphy, Teri, and Auveen Woods. 2014. Turkey's International Development Framework Case Study: Somalia. IPC-MERCATOR Policy Brief. Istanbul: Istanbul Policy Center. http://ipc.sabanciuniv.edu/wp-content/uploads/ 2014/02/SOMALIISBN11.pdf

Sassounian, Harut. 2014. Why the UN Rejected Turkey's Bid for a Security Council Seat. The Huffington Post, October 28. Accessed October 26, 2015. http://www.huffingtonpost.com/harut-sassounian/why-the-un-rejectedturke_b_6036878.html

Turkish Cooperation and Coordination Agency. 2012. Turkish Cooperation and Coordination Agency Annual Report 2011. Ankara.

- 2013. Turkish Cooperation and Coordination Agency Annual Report 2012. Ankara.

- 2014a. Turkish Cooperation and Coordination Agency Annual Report 2013. Ankara.

- 2014b. Turkish Development Assistance 2013. 2014b. Ankara.

- 2016. Turkish Development Assistance: From Turkey to the World2014 Report. Ankara. http://www.tika.gov.tr/upload/2016/INGILIZCE\% 20SITE\%20ESERLER/KALKINMA\%20RAPORLARI/DA\%20Report\%20 2014.pdf 
Turkish Ministry of Foreign Affairs. 2016. Candidacy of the Republic of Turkey to the United Nations Security Council for the period 2015-2016. Accessed January 30, 2017. http://www.mfa.gov.tr/candidacy-of-the-republic-of-turkeyto-the-united-nations-security-council-for-the-period-2015-2016.en.mfa

Turkiye Bursları. n.d. Türkiye Bursları Scholarships. Accessed January 30, 2017. http://www.turkiyeburslari.gov.tr/index.php/en/

United Nations Security Council. 2011. United Nations Security Council, 6472nd Meeting. New York. Accessed June 20, 2015. http://www.securitycouncilreport.org/atf/cf/\%7B65BFCF9B-6D27-4E9C-8CD3-CF6E4FF96FF9\%7D/ TL\%20S\%20PV\%206472.pdf

United Nations High Commissioner on Refugees. 2017. Syrian Regional Refugee Response: Inter-agency Information Sharing Portal. Accessed February 12, 2017. http://data.unhcr.org/syrianrefugees/regional.php

Onur Sazak is Advocacy and Coordination Manager at Support to Life, and Ph.D. candidate in Political Science at Sabanc1 University, Istanbul.

Auveen Elizabeth Woods is Researcher, Istanbul Policy Center, Sabancı University, Istanbul.

Open Access This chapter is licensed under the terms of the Creative Commons Attribution 4.0 International License (http://creativecommons.org/licenses/ by $/ 4.0 /$ ), which permits use, sharing, adaptation, distribution and reproduction in any medium or format, as long as you give appropriate credit to the original author(s) and the source, provide a link to the Creative Commons license and indicate if changes were made.

The images or other third party material in this chapter are included in the chapter's Creative Commons license, unless indicated otherwise in a credit line to the material. If material is not included in the chapter's Creative Commons license and your intended use is not permitted by statutory regulation or exceeds the permitted use, you will need to obtain permission directly from the copyright holder.

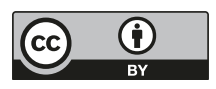

